TITLE:

\title{
Sleep-disordered breathing at an early stage of amyotrophic lateral sclerosis(Abstract_要旨)
}

\author{
AUTHOR(S): \\ Kimura, Kaku
}

\section{CITATION:}

Kimura, Kaku. Sleep-disordered breathing at an early stage of amyotrophic lateral sclerosis. 京都大学, 1999, 博士(医学)

ISSUE DATE:

1999-03-23

URL:

http://hdl.handle.net/2433/181697

RIGHT: 
氏名亲哲格

学位 (専攻分野) 博士（医、学）

学 位記 番号医 博 第 2081 号

学位授与の日付 平成 11 年 3 月 23 日

学位授与の要件 学位規則第 4 条第 1 項該 当

研究科. 専攻医学研究科脳統御医科学系専攻

学位論文題目 Sleep-disordered breathing at an early stage of amyotrophic lateral sclerosis

（筋萎縮性側索硬化症の病初期における睡眠時呼吸障害）

(主査)

論文調查委員 教 授川口三郎 教 授 三好功峰 教 授柴 崎 浩

\section{論文 内 容 の 要旨}

神経筋疾患は，しばしば呼吸筋の筋力低下のため呼吸不全を伴い，日中は呼吸障害を呈さない患者においても，睡眠時に は呼吸障害を認めることがある。筋萎縮性側索硬化症（ALS）では呼吸筋の筋力低下に加えて球麻㾇も出現し，後者が睡眠 時呼吸障害の発生や重症度に影響するため，進行例では睡眠時呼吸障害を起こすことが報告されている。また，日中には呼 吸不全がない臨床的に病初期のALS患者でも，睡眠時呼吸障害が存在する可能性があるが，ALSにおいて病初期の患者を対 象として睡眠時呼吸障害を評価した研究はまだない。そこで，携帯型簡易睡眠モニターを用いて，病初期のALS患者の睡眠 時呼吸障害の出現ならびにその程度を検討した。

対象は，日中に呼吸困難や睡眠障害を訴えないALS患者18例である。ALS診断基準に適合し，日常生活上，歩行が十分可 能あるいは上肢の運動が障害されていないものを病初期ALSとした。さらに, 球麻疸症候の有無により, 球麻㾝優勢型11例 と非球麻疩型 7 例の 2 群に分けて検討した。

神経学的診察，Norrisスケール，Epworth睡眠スケールを含む睡眠アンケート，および日中の呼吸機能（肺活量，一秒量， 最大換気量, 動脈血ガス）測定を施行後，携帯型簡易睡眠モニターを用いて呼吸障害指数，無呼吸／低呼吸の型及び動脈血 酸素飽和度を定量的に評価した。

いずれの例でも，呼吸困難や睡眠障害の自覚，心疾患の既往は認めず，睡眠アンートにおいても問題はなかった。球麻痺 優勢型，非球麻瘏型の両群間で年齢，体容量指数に有意差はなく，䍜病期間，Norrisスケールに有意差が認められた。

睡眠時のモニターでは，球麻疩優勢型，非球麻㾇型の両群間で平均呼吸障害指数に有意差はなかったが，前群11例のうち 3例に睡眠時呼吸障害を認めた。しかし, 球麻㾇優勢型ALS患者で, 呼吸障害指数と他の指数（罹病期間, Norrisスケール, 体容量指数，Epworth睡眠スケール）との間に相関関係がなかったため, この3 例に共通するその他の特徴的な要因を見い 出すことはできなかった。

睡眠時呼吸障害を示した 3 例の患者において，無呼吸／低呼吸の様式に多様性があり，この原因には異なった機構が考え られた。睡眠時呼吸障害が比較的軽度な 1 例では，無呼吸／低呼吸が主にREM睡眠時に出現した。今までの研究結果では, 神経筋疾患でREM睡眠中に中枢型無呼吸が認められた場合, REM睡眠中ガス交換に寄与する筋は横隔膜のみとなる理由か ら，横隔膜の筋力低下が疑われる。従って，この患者においては，日中の呼吸機能に反映するほどではない横隔膜の筋力低 下が示唆された。他の 2 例の睡眠時呼吸障害は，ALS発症以前よりいびきがあること，呼吸障害指数が比較的高く殆どが閉 塞型呼吸障害であったため, 閉塞型睡眠時無呼吸をALS発症前より既に呈していたことを完全には否定できない。しかし， いびきの他には, 閉塞型睡眠時無呼吸症候群に特徵的な症状を呈していなかったことから, 元来上気道の部分的閉塞があり, それに球麻疩症状が加わったために睡眠中に完全な無呼吸を起こした可能性がある。

臨床評価と日中の呼吸機能検查のみでは，このような病初期のALS患者が睡眠時呼吸障害を呈しているか否かを予想する ことはできず，病初期のALS患者の睡眠時呼吸障害は睡眠中の検查ではじめて検出が可能であり，さらにこれは呼吸筋及び 
横隔膜の筋力低下, 球麻疩の評価につながる所見となりうるものと考えられる。

\section{論 文 審 査 の 結 果 の 要 旨}

筋萎縮性側索硬化症（ALS）の進行例では，呼吸筋の筋力低下のため, 睡眠時呼吸障害が報告されている。本研究では, 日中には呼吸不全を示さない病初期のALS患者において睡眠時に呼吸障害が出現するかどうか，そしてもしあればその程度 を明らかにすることを目的とした。日中の呼吸機能が正常なALS患者18例を対象とし，携帯型簡易睡眠モニターにより口鼻 呼吸, 胸郭の呼吸運動, 動脈血酸素飽和度, 心拍数, いびき, および体位の変動を測定した。球麻疩優勢型11例中 3 例に呼 吸障害指数の異常を認めたが, 非球麻痺型 7 例では異常を認めなかった。異常を認めた 3 例中 1 例では, レム睡眠時の中枢 型無呼吸または低呼吸, 他の 2 例では閉塞型呼吸障害を示し, その原因は症例によって異なることが示唆された。すなわち, 病初期のALS患者では, 日中の呼吸機能検査のみでは睡眠時呼吸障害の有無を予想することは不可能であり, 睡眠時の呼吸 評価により初めてその検出が可能であった。本研究により，日中には呼吸不全のないALSの病初期にも睡眠時呼吸障害が起 こり得ることが初めて明らかになった。

以上の研究は，病初期のALS患者の睡眠時呼吸障害の病態の解明に貢献し，睡眠時の呼吸管理に寄与するところが多い。 従って, 本論文は博士（医学）の学位論文として価值あるものと認める。

なお，本学位授与申請者は，平成11年 1 月 8 日実施の論文内容とそれに関連した試問を受け，合格と認められたものであ る。 